\section{A methodological study on improving a new orthodontic face mask}

\section{Yeni bir ortodontik yüz maskesi geliştirilmesi üzerine metodolojik bir çalışma}

\author{
Assist Prof. Nurhat Özkalaycı \\ University of Bülent Ecevit, Faculty of Dentistry, \\ Department of Orthodontics, Zonguldak.
}

Assoc. Prof. Mehmet Yetmez

University of Bülent Ecevit, Faculty of Engineering,

Department of Mechanical Engineering, Zonguldak.

Received: 19 September 2016

Accepted: 25 December 2016

DOI: 10.5505/yeditepe.2017.53825

\section{Corresponding author:}

Assist Prof. Nurhat Özkalaycı

University of Bülent Ecevit, Faculty of Dentistry,

Department of Orthodontics, 67600 Zonguldak

Tel: 0905055827411

Email: dt.nurhat@yahoo.com

\section{SUMMARY}

Introduction: The aim of this study is to present and evaluate a new monitoring system attached to forehead part of face mask for tracking orthodontic face mask usage time and regularity.

Methods: The new monitoring system consists of three main parts as main body, slot cover and sensor. The main body includes two lateral fixer, a median fixer, sensor insertion slot and eight screw holes. After completing the assembly procedure for the main part, the sensor is programmed and inserted to its slot and then the cover is screwed. The system was tested under laboratory condition.

Results: Detailed analysis of the post study data showed that the system measured the attachment and detachment period correctly. The new type orthodontic face mask can monitor the wearing time and regularity.

Conclusion: Face mask therapy is a crucial for correction of sagittal maxillary deficiency. Total wearing time and regularity is main factors to reach to a success level of this orthodontic and orthopedic treatment. Objective and scientific monitoring system proposed here may help the clinicians for difficult, long and expensive treatment. Conclusion of present study show that the system proposed is suitable for the further face mask usage.

Keywords: Face mask, orthodontics, maxillary deficiency, monitoring system

\section{ÖZET}

Amaç: Çalışmanın amacı ortodontik yüz maskesi kullanım süresi ve düzenini takip etmek amacıyla yüz maskesinin alın kısmına takılan yeni bir izleme sisteminin sunulması ve değerlendirilmesidir.

Gereç ve Yöntem: Yeni izleme sistemi ana gövde, yuva kapağ ve sensör olmak üzere 3 ana parçadan oluşmaktadır. Ana gövde iki adet yan sabitleyici, bir adet orta sabitleyici, sensör takma yuvası ve sekiz vida deliğinden oluşmaktadır. Ana gövdedeki tüm parçaların yerleştirilmesini takiben sensör programlanmış ve yuvaya yerleştirilmiştir daha sonra kapak sabitlenmiş̧ir. Sistem laboratuvar koşullarında test edilmiştir. Bulgular: Çalışma sonunda elde edilen verinin detaylı analizi göstermiştir ki izleme sistemi takma ve sökme süreçlerini doğru bir şekilde takip etmektedir. Yeni tipteki ortodontik yüz maskesi takma sürelerini ve düzenini izleyebilmektedir.

Sonuç: Yüz maskesi tedavisi sagital yöndeki üst çene yetersizliğinin düzeltilmesinde elzemdir. Toplam kullanım süresi ve düzenli kullanım ortodontik ve ortopedik tedavinin başarısını etkileyen temel faktörlerdir. Objektif ve bilimsel olarak bu sürecin izlenmesi bu meşakkatli, uzun ve pahalı tedavide klinisyenlere büyük katkı sağlayacaktır. Bu çalışmanın sonucu göstermiştir ki yeni izleme sistemi yüz maskesi kullanımı için uygundur.

Anahtar Kelimeler: Yüz maskesi, ortodonti, üst çene yetersizliği, izleme sistemi 


\section{INTRODUCTION}

Orthodontic face mask as an extra oral orthodontic appliance has been used for improving maxilla's anterior growth during last century. ${ }^{1-3}$ Many clinicians use active growth period face mask therapy for patients with sagittal maxillary deficiency. ${ }^{4}$ Actually, this type of therapy is considered due to the fact that face mask works well and provide proper correction of sagittal maxillary deficiency. ${ }^{5}$ Outcomes of a successful treatment with a face mask depend on good patients' compliance. Moreover, to provide sagittal maxillary protraction, patients should wear face masks regularly and sufficient time of period according to clinicians' recommendations. ${ }^{6}$ Poor patient compliance decreases the success rate of face mask therapy. Ages of

face mask therapy patients are between 10-14 years old and all types of face mask possess aesthetically poor appearance. ${ }^{7}$ Combination of these two factors, (i.e., teenage period and poor aesthetics) can lead to a major disadvantage. These very young patients do not require wearing orthodontic face mask due to aesthetic reasons. Clinicians try to learn the level of patients' compliance with some subjective methods like asking family members, school friends and/or teacher. But these subjective methods are not reliable and scientific. Consequently, a need of measurement technique appears at this point. It is known that objective electronic medical records of face mask usage can improve the clinician's productivity. ${ }^{8}$ In other words, there is increasingly a need of objective monitoring of face mask therapy and medical records. And, only a few devices are available to quantify extra oral appliance wearing time and usage regularity up till now.

In this study, a new monitoring system is introduced to provide proper face mask usage and regularity.

\section{MATERIAL AND METHODS}

The system is designed as three parts: main body, sensor and slot cover (Figure 1).

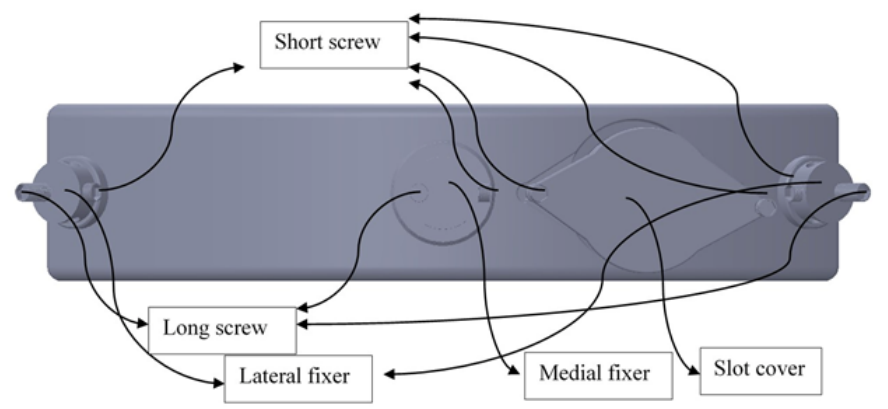

Figure 1: Frontal view of the main body and slot cover of system.

Main body consists of two lateral fixer, a medial fixer, a sensor slot and three long screws on frontal surface.
Three long screws are used to increase the strength of lateral and medial fixers. The fixers have holes for face masks' vertical arms and lateral screw mechanisms to provide the retention of vertical arms. And, there is a sensor insertion slot on the left side of frontal surface of main body as given in Figure 2 .

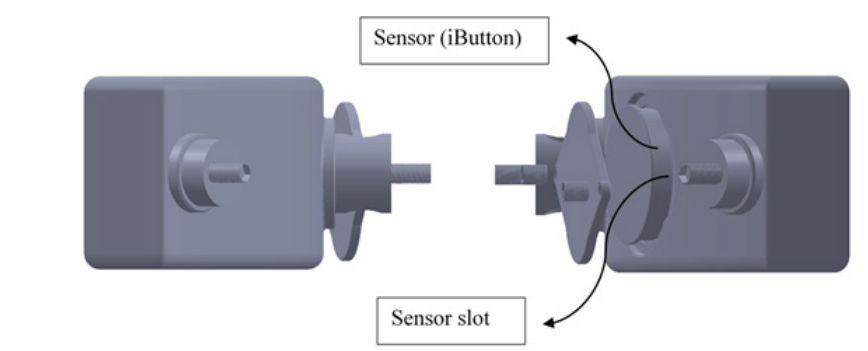

Figure 2: Lateral view of the system.

The sensor insertion slot has a cover close with the help of two screw. On the backward surface of main body includes a prominence called forehead stabilizer (see Figure 3).

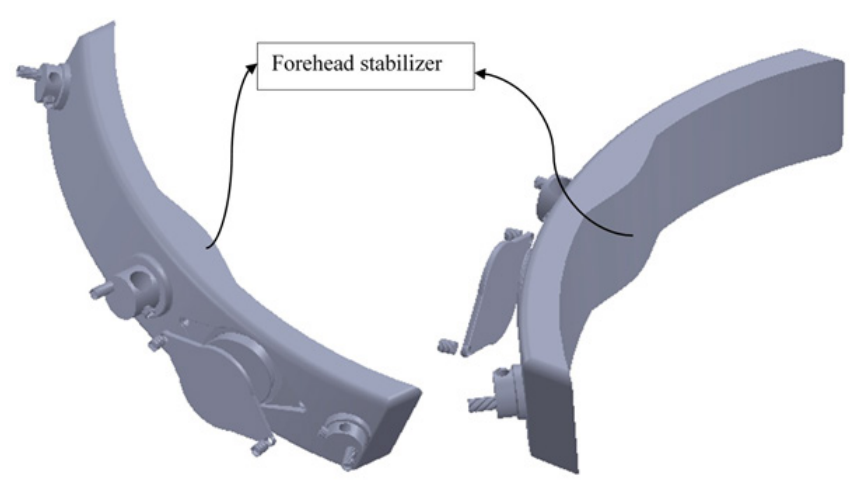

Figure 3: Perspective view of system.

The system is completed by using a general purpose CAD code Solidworks (Solidworks Corp, Waltham, Massachusetts, USA). Then, the main body and cover are produced by a 3D printer (Ultimaker 2+,Ultimaker B.V., Watermolenweg, Geldermalsen, The Netherlands).

Additionally, Thermochron iButton DS1921H-F5\# (Maxim Integrated, Rio Robles, San Jose, CA, USA) is used in the system. Temperature range of DS1921H measurement is between $15^{\circ} \mathrm{C}$ to $45^{\circ} \mathrm{C}$. It is noted that the size of DS1921H is proper for the sensor insertion slot of new monitoring system. DS1921H can be connected to computer by using an iButton reader (Blue Dot Receptor, Model DS1402D-DR8). The iButton is programmed to measure the temperature by using a data acquisition software (32-Bit iButton-TMEX Runtime Environment).

Steps of the assembly of the system are as follows: (1) Placement of long screws in to lateral and medial fixers, (2) Sensor insertion after programming, and (3) Placement of sensor insertion slot cover and placement of short screws.

After the assembly procedure, the monitoring system is 
ready for attaching to the face masks. Simply, this procedure can be done by either medial or lateral fixer. For example, if the type of face mask is petit, median fixer is used. In this experiment, the delaire type face mask is chosen to use lateral fixers. Test setup with connections is presented in Figure 4.

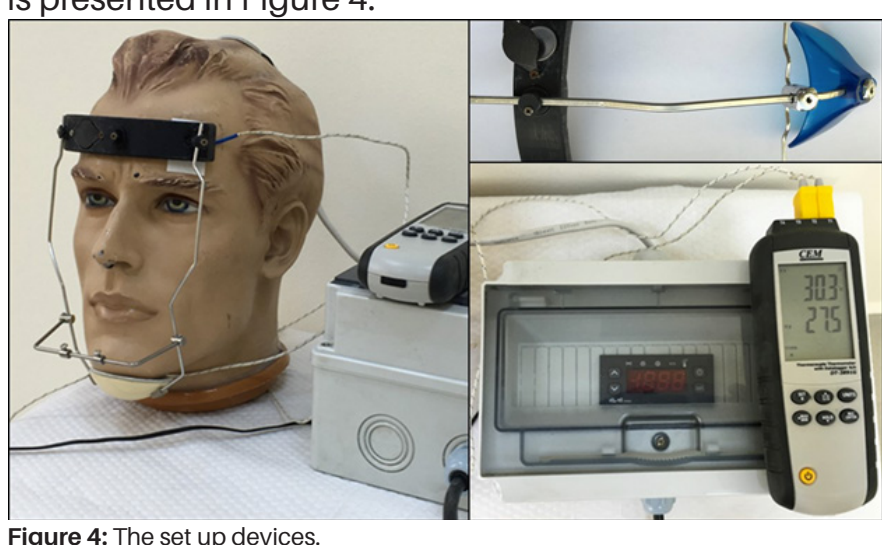

The electrically thermostat controlled elastic resistance is placed in a carbon fiber human head filled with water. Then, the model is heated up to $37^{\circ} \mathrm{C}$ and is carefully controlled with respect to water level and surface temperature.

Thus, the monitoring system proposed is placed on heater with help of elastics. Attachment weekly process is as follows: Week 1: Attachment between 00:00 pm to 07:00 am, Week 2: Attachment between 07:00 am to 07:00 pm, Week 3: Attachment between 07:00 pm to 00:00 pm and Week 4: Detachment.

\section{RESULTS}

Results are given in Figures 5 and 6. One one hand, Figure 5 indicate that (i) elastics are suitable for stabilization of the face mask with monitoring system on the forehead of human head model, (ii) one week period shows that surface temperature of forehead part of the model is periodically stable.

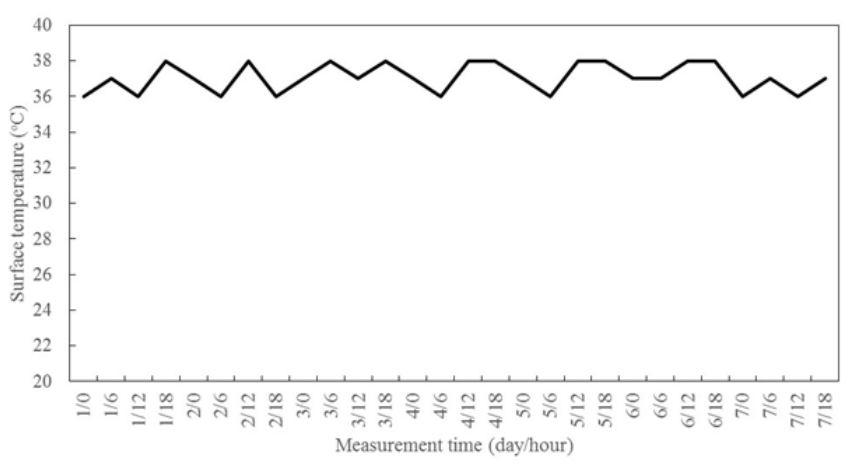

Figure 5: Surface temperature of the system during one week.

On the other hand, Figure 6 says that the system temperature is in the range of $36-38^{\circ} \mathrm{C}$ during attachment period and $22-27^{\circ} \mathrm{C}$ detachment period.

One can easily complete montage of the system and do programming it via the iButton. There is no need of a lab- oratory technician or a computer expert to prepare the system for usage. Any clinician can not only manage the system but also evaluate the results easily.

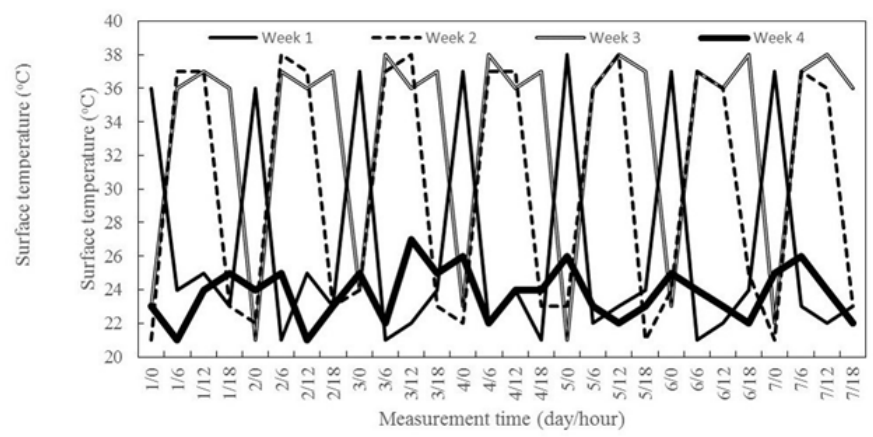

Figure 6: Surface temperature of the system during four weeks.

\section{DISCUSSION}

Face masks has been used for orthodontic purposes especially correction of sagittal maxillary deficiency. ${ }^{9}$ This medical system is working with applied orthodontic force to the maxilla anteriorly during 12-14 hours per day. Success level of this system is directly related to the face mask. In modern orthodontic practice, although there are perfect designs of face mask, the mask is only shaped according to the mechanical requirements. ${ }^{10}$ The mask is produced to supply enough anchorage level to eliminate the side effects of protraction forces. Therefore, there is to be a monitoring system to control the system accurately. DS1921H-F5 is appropriate for the new monitoring system, which provides required data due to its characters. Its dimensions are proper for sensor slot of system and can be easily insert in it. Measurement gap of DS1921H is chosen for monitoring body temperature of humans. In literature, this type of iButton is used for determination of body temperature of humans during critical processes in treatment process. ${ }^{11-17}$ Memory capacity and battery life of DS1921H-F5 are enough for the purpose of new monitoring system. The iButton possesses a clock memory and automatically wakes up. Especially, it can measure 2048 temperature values and store it after momentary contact.

Clinicians recommend patients to use face masks at night while sleeping due to the high growth factor release. The face masks are worn in closed places like bedrooms which in environmental temperature is mostly near to laboratory room temperatures. There are approximately minimum $6^{\circ} \mathrm{C}$ and maximum $16^{\circ} \mathrm{C}$ temperature difference deviation between human skin and closed room temperature. On one hand, extremely hot or cold weather can affect the level of temperature of room. On the other hand, the envi- 
ronmental temperatures cannot exceed the human body temperatures. Otherwise patient cannot live.

\section{CONCLUSION}

The data of the system provided correct wearing time and regularity. The new orthodontic face mask can monitor patients' behavior and cooperation. Future studies should be about the clinical use of this new monitoring system and orthodontic face mask.

\section{REFERENCES}

1. M.P. Major, J.K. Wong, H. Saltaji, P.W. Major and C. Flores-Mir. Skeletal Anchored Maxillary Protraction for Midface Deficiency in Children and Early Adolescents with Class III Malocclusion: A systematic Review and Meta-Analysis. Journal of the World Federation of Orthodontists 2012; 1: e47-e54.

2. P. Ngan and W. Moon. Evolution of Class III Treatment in Orthodontics. American Journal of Orthodontics and Dentofacial Orthopedics 2015; 148: 22-36.

3. S. Pattanaik and S. Mishra. Treatment of Class III with Face mask Therapy. Case Reports in Dentistry 2016; Article ID 6390637, 1-8.

4. H.J. De Clerck and W.R. Proffit. Growth Modification of the Face: A Current Perspective with Emphasis on Class III Treatment. American Journal of Orthodontics and Dentofacial Orthopedics 2015; 148: 37-46.

5. C.T. Hino, L.H. Cevidanes, T.T. Nguyen, H.J. De Clerck, L. Franchi and J.A. McNamara Jr. Three-Dimensional Analysis of Maxillary Changes associated with Face mask and Rapid Maxillary Expansion Compared with Bone Anchored Maxillary Protraction. American Journal of Orthodontics and Dentofacial Orthopedics 2013; 144: 705-714. 6. D. Gencer, E. Kaygisiz, S. Yüksel and T. Tortop. Comparison of Double-Plate Appliance/Face mask Combination and Face mask Therapy in Treating Class III Malocclusions. The Angle Orthodontist 2014; 85: 278-283.

7. [P.V.P. Oltramari-Navarro, R.R.D. Almeida, A.C.D.C.F. Conti, R.D.L. Navarro, M.R.D. Almeida and L.S.A.F.P. Fernandes. Early Treatment Protocol for Skeletal Class III Malocclusion" Brazilian Dental Journal 2013; 24: 167 173.

8. D.X. Gu, C.Y. Liang, X.G. Li, S.L. Yang and P. Zhang. Intelligent Technique for Knowledge Reuse of Dental Medical Records Based on Case-Based Reasoning. Journal of Medical Systems 2008; 34: 213-222.

9. J.C. Palma, N. Tejedor-Sanz, M.D. Oteo and J.A. Alarcón. Long-term Stability of Rapid Maxillary Expansion Combined with Chincup Protraction Followed by Fixed Appliances. The Angle Orthodontist 2014; 85: 270-277.

10. U.N. Soni, M.J. Baheti and N.G. Toshniwal. Orthodontic Headgear and Ocular Injuries. Journal of Advanced Medical and Dental Sciences Research 2014; 2: 1-7.
11. P. Foltyński, B. Mrozikiewicz-Rakowska, P. Ładyżyński, J.M. Wójcicki and W. Karnafel. The Influence of Ambient Temperature on Foot Temperature in Patients with Diabetic Foot Ulceration. Biocybernetics and Biomedical Engineering 2014; 34: 178-183.

12. H.R. Tranel, E.A. Schroder, J. England, W.S. Black, H. Bush, M.E. Hughes, K.A. Esser and J.L. Clasey. Physical Activity, and not Fat Mass is a Primary Predictor of Circadian Parameters in Young Men. Chronobiology International 2015; 32: 832-841.

13. F. Piotr, L. Piotr, B. Martin, G. Julius, M.M. Karolina, M. Maria, S. Stanislawa and C. Anna. Continuous Monitoring of Feet Temperature Using a Data Logger with Wireless Communication. Biocybernetics and Biomedical Engineering 2012; 32: 59-64.

14. M.R. Boon, L.E. Bakker, R.A. van der Linden, L. Pereira Arias-Bouda, F. Smit, H.J. Verberne, W.D. van Marken Lichtenbelt, I.M. Jazet and P.C. Rensen. Supraclavicular Skin Temperature as a Measure of 18F-FDG Uptake by BAT in Human Subjects. PLoS One 2014; 9: 1-8.

15. E.A. Gil and X.L. Aubert, Beersma DGM. Ambulatory Estimation of Human Circadian Phase using Models of Varying Complexity based on Non-Invasive Signal Modalities. 36th Annual International Conference of the IEEE Engineering in Medicine and Biology Society 2014; p2278-2281.

16. L. Brabyn, P. Zawar-Reza, G. Stichbury, C. Cary, B. Storey, D.C. Laughlin and M. Katurji. Accuracy Assessment of Land Surface Temperature Retrievals from Landsat 7 ETM + in the Dry Valleys of Antarctica using iButton Temperature Loggers and Weather Station Data. Environmental Monitoring and Assessment 2013; 186: 2619-2628.

17. B. McFarlin, A. Venable, R. Williams and A. Jackson. Comparison of Techniques for the Measurement of Skin Temperature during Exercise in a Hot, Humid Environment. Biological Sport 2015: 32: 11-14. 